\title{
Chitosan - a non-invasive approach for the preservation of historical textiles
}

\author{
DOI: $10.35530 / I T .071 .06 .1756$
}

\author{
EVA BOU-BELDA \\ LILIANA INDRIE \\ DORINA CAMELIA ILIEȘ \\ NICOLAIE HODOR
}

\author{
ZHARAS BERDENOV \\ GRIGORE HERMAN \\ TUDOR CACIORA
}

\section{ABSTRACT - REZUMAT}

\section{Chitosan - a non-invasive approach for the preservation of historical textiles}

Old textiles represent important samples of the mobile cultural heritage, having implications on the social and spiritual life of each population. In order to keep them in the best condition, it is necessary to implement methods to prevent damages, but also to rehabilitate and clean the already affected fabrics. In the case of textiles that need to be treated, a fundamental thing is the unaltered preservation of the initial characteristics of the materials, even after the interventions. The aim of our study is to test the feasibility of a non-invasive alternative to usual chemicals for cleaning textiles; Chitosan's antimicrobial and cleaning effects on a pair of Romanian traditional cotton trousers, from Maramures area was analyzed. A few images were taken from SEM of untreated and treated fabric with Chitosan solution using different magnifications, in order to check the changes on the fabric surface. The purpose was to observe if there are some color changes after Chitosan treatment, so the CIELAB color values $(L, a, b)$ of untreated and treated samples were analyzed. The analysis of the treated samples revealed strong antimicrobial effects of Chitosan.

Keywords: Chitosan, old traditional clothing, SEM images, colour measurement

\section{Chitosanul - o abordare neinvazivă pentru prezervarea textilelor istorice}

Materialele textile vechi reprezintă eșantioane importante ale patrimoniului cultural mobil, având implicații în ceea ce privește viața socială și spirituală a fiecărei populații. Pentru conservarea acestora în stare cât mai bună, este necesar a se implementa metode de prevenție, dar și de reabilitare și curățare a țesăturilor deja afectate. În cazul materialelor textile care necesită a fi tratate, un lucru fundamental îl reprezintă păstrarea nealterată a caracteristicilor inițiale ale materialelor, chiar și după efectuarea intervențiilor. Prezentul studiu își propune a proba viabilitatea unei alternative neinvazive la substanțele chimice obișnuite pentru curățarea materialelor textile. Au fost analizate efectele antimicrobiene și de curățare ale chitosanului asupra unei perechi de pantaloni tradiționali românești, din bumbac, din zona Maramureșului. Câteva imagini SEM au fost preluate de pe țesătura netratată și apoi tratată cu soluție de chitosan, la diferite grade de mărire, pentru a verifica modificarea suprafetei materialului textil. Scopul a fost să observăm dacă după tratamentul cu chitosan există unele schimbări de culoare, deci, eșantioanele netratate și tratate au fost analizate in spatiul color CIELAB (L, a, b). Analiza probelor tratate a evidențiat efecte antimicrobiene puternice ale chitosanului.

Cuvinte-cheie: Chitosan, îmbrăcăminte tradițională veche, imagini SEM, măsurători de culoare

\section{INTRODUCTION}

Old textiles, and especially those that make up the traditional costume [1], are an important part of the cultural heritage [2-4]. They must be kept in good condition because they represent elements of individual, local and national identity [5]. Some of the fabrics can provide valuable information on the everyday context, the status of the society and its history [6]. The state of preservation of textiles depends largely on the type and composition of the fibers, the dyes used their history of usage and storage conditions [5]. Over time, textiles are subject to negative effects due to their aging, such as their yellowing [7, 8] and low tear resistance $[9,10]$, but also the development of bacteriological microflora [5, 11-14] and impurities [15]. In order to preserve them as long as possible, the process of textile degradation must be understood and both preventive and reactive solutions must be sought [16]. Textiles already in the process of degradation must be subjected to chemical treatments in order to be properly cleansed and preserved. Looking back at the studies undertaken in the field, it can be seen that for the treatment of textiles, both non-invasive chemicals [17-19] and some harmful ones for fabrics are used [20].

Chitosan is one of the most powerful natural polysaccharides of biotic origin, derived from chitin, with great applicability in different fields [21, 22]. Among the fundamental properties of Chitosan are the strong disinfectant and antimicrobial effects [23, 24] while being less harmful to the human body $[25,26]$ and to the support materials [27, 28].

These being known, the present study aims to analyze through SEM images [29-31] and spectrophotometric [32] images the effects that occur after the application of Chitosan on an old piece of traditional [33] cotton clothing. 


\section{MATERIALS AND METHODS}

In order to carry out the study, it was considered the analysis of samples of materials taken from a traditional Romanian trousers called "gatii" (leggings) from the Maramures area (figure 1), made from cotton, which is one of the main materials the Romanian traditional folk costumes are mainly made of. The value of the piece is given by the conventional way it was produced (in the loom) and by its age, dating from the first half of the last century.

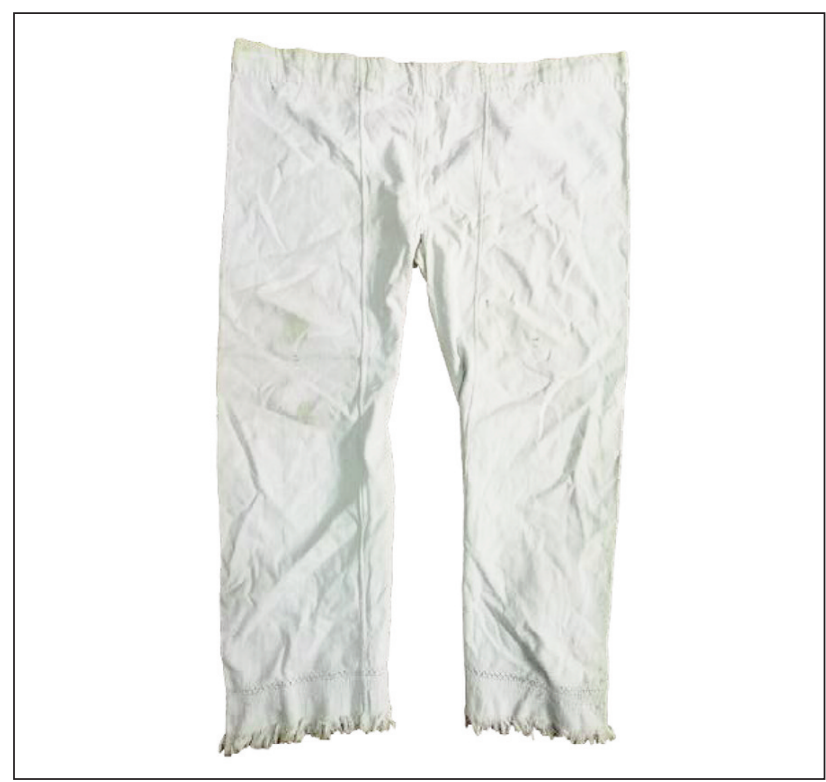

Fig. 1. The traditional Romanian trousers from which the samples were taken

Chitosan powder (medium molecular weight, viscosity $200.000 \mathrm{cps}$, CAS 9012-76-4) was purchased from the Aldrich Chemical and acetic acid (80\%) was sumministrated by Panreac. Samples were treated by padding what allows impregnating fabric; we used a 2608 TEPA foulard. The bath treatment for padding comprised $10 \mathrm{~g} / \mathrm{l}$ of Chitosan and $6 \mathrm{ml} / \mathrm{l}$ of acetic acid. The pick-up obtained was around 90-95\%, this means that $90 \mathrm{~g}$ of bath treatment were absorbed in $100 \mathrm{~g}$ of fabric. Samples were dried at $85^{\circ} \mathrm{C}$ and cured for 30 seconds at $130^{\circ} \mathrm{C}$.

In order to compare fabric surface before and after the treatment, untreated and treated samples were characterized by Zeiss model ULTRA 55 field emission Scanning Electron Microscope (FESEM) (Oxford instruments). Each sample was fixed on a standard sample holder and sputter coated with plati. Samples were then examined with suitable acceleration voltage and magnification and prepared for colour measurement, which was carried out by following a standard procedure. Colour values were evaluated in terms of CIELAB values $\left(L^{*}, a^{*}, b^{*}\right)$ using illuminant $\mathrm{D} 65 / 10^{\circ}$ observer on Minolta CM-3600d UV-visible spectrophotometer.

Total colour difference of dyed cotton samples was obtained using the following equation:

$$
(\Delta \mathrm{Eab})=\sqrt{(\Delta \mathrm{L})^{2}+(\Delta \mathrm{a})^{2}+(\Delta \mathrm{b})^{2}}
$$

To determine the degree of bacteriological contamination of the folk piece of clothing, the Koch sedimentation method was used. Petri dishes were positioned on the textile materials for sampling, both before and after applying Chitosan powder.

\section{RESULTS AND DISCUSSIONS}

To check the changes on the fabric surface, some images from SEM were taken from the untreated and treated fabric with Chitosan solution using different magnifications. In figure 2 , we can observe that untreated fabric (A1, B1, C1) shows some impurities or dirt on the surface which can't be noticed on the surface of the treated fabric (A2, B2, C2).

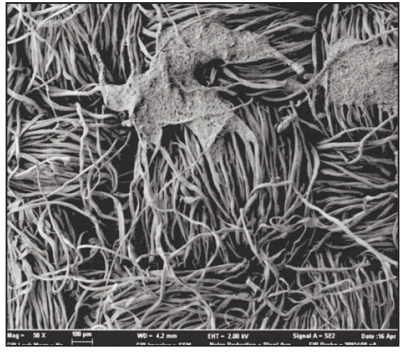

A1

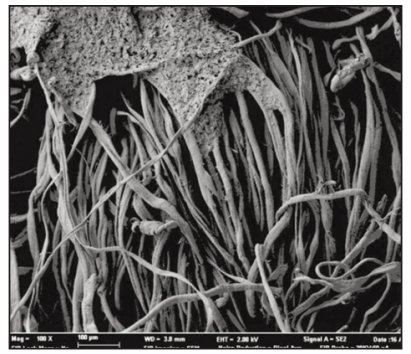

B1

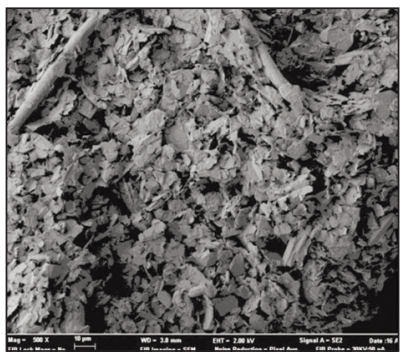

C1

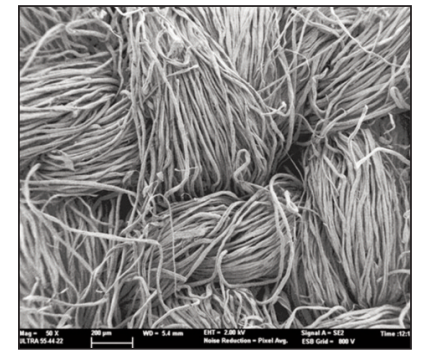

A2

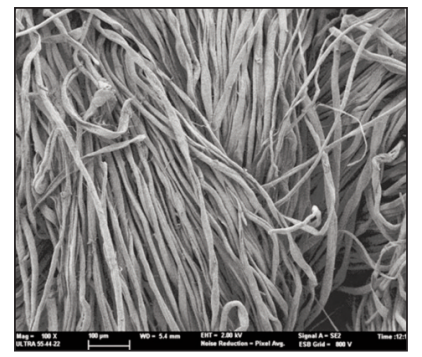

B2

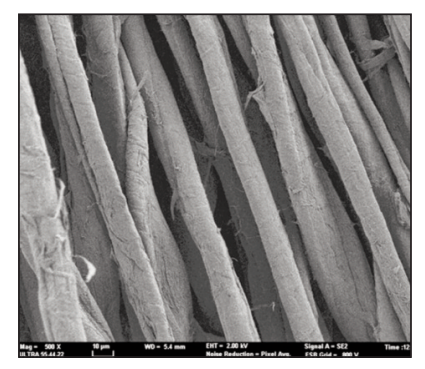

C2
Fig. 2. SEM images of: $A 1, B 1, C 1$ - untreated fabric and $A 2, B 2, C 2$ - treated fabric using different magnifications (A1, A2 with 50x, B1, B2 with $100 x$ and $C 1, C 2$ with $500 \times$ )

In order to check if there are some colour changes after Chitosan treatment CIELAB colour values $(L, a, b)$ of untreated and treated samples were analyzed, these results are given in table 1.

$L^{*}$ values refer to light-dark values from 100 to 0 representing white to black, $a^{*}$ values range from negative (green) to positive (red) and $b^{*}$ values range from negative (blue) to positive (yellow) and the total colour is given by $\Delta \mathrm{Eab}$. Results show the effect of Chitosan treatment, as $L$ value shows the lightness is higher when the fabric is treated and it is significant $b$ value, as this parameter shows the yellowness and after the treatment sample gets decrease this value. 
Table $1 \quad[35,36]$. The strong antimicrobial effects of Chitosan were confirmed by analysing the COLORIMETRIC DATA OF UNTREATED AND TREATED FABRIC examination of the treated samples.

\begin{tabular}{|c|c|c|c|c|}
\hline Fabric type & $\mathbf{L}$ & $\mathbf{a}$ & $\mathbf{b}$ & $\Delta$ Eab \\
\hline Untreated & $86.081 \pm 0.16$ & $1.452 \pm 0.19$ & $-1.791 \pm 0.19$ & - \\
\hline Treated & $87.221 \pm 0.13$ & $1.388 \pm 0.11$ & $-2.119 \pm 0.11$ & $1.22 \pm 0.11$ \\
\hline
\end{tabular}

\section{CONCLUSIONS}

The current study indicates that the application of Chitosan on the historical textiles in a degradation state is a non-invasive

Early bacteriological testing revealed the presence of Klebsiella bacteria with the Klebsiella pneumonia subtype. This is a gram-negative bacillus, ubiquitous in nature, which normally colonizes the intestinal tract, pharynx and skin in humans. It is responsible for severe infectious epidemics (respiratory tract infections, urinary tract, digestive, systemic and nosocomial), constantly increasing globally [34]. The mode of transmission is mainly represented by the direct contact between the skin (containing wounds or burns) and the contaminated surfaces, much less through the air path by breathing from the oropharynx alternative for cleaning and improving their conservation status. After application, the SEM images showed an improvement in the degree of cleaning of the materials, the fabrics remaining intact. The material became more intense white, due to the fact that the dirt was largely removed. At the same time, favourable conditions have been created for it to be worn, without endangering human health.

\section{ACKNOWLEDGEMENT}

The research was possible by equal scientific involvement of all authors and acknowledges the support of the Grant PN-III-P1-1.2-PCCDI-2017-0686.

\section{REFERENCES}

[1] Petroviciu, I., Vanden Berghe, I., Cretu, I., Albu, F., Medvedovici, A., Identification of natural dyes in historical textiles from Romanian collections by LC-DAD and LC-MS (single stage and tandem MS), In: Journal of Cultural Heritage, 2012, 13, 1, 89-97

[2] Mihincău (Mihele), D.C., Ilieș, D.C., Koroleva, Y., Herman, G.V., The study of indoor microclimate on wooden churches to be included among Oradea's representative sights, In: GeoJournal of Tourism and Geosites, 2019, 26, $3,737-750$

[3] Ilieș, D.C., Oneț, A., Marcu, Fl.M., Gaceu, O.R., Timar, A., Baias, Șt., Ilieș, A., Herman, G.V., Costea, M., Țepelea, M., Josan, I., Wendt, J., Investigations regarding the air quality in the historic wooden church in Oradea city, Romania, In: Environmental Engineering and Management Journal, 2018, 17, 11, 2731-2739

[4] Ilieș, D.C, Onet, A., Wendt, J.A., Ilieș, M., Timar, A., Ilieș, A., Baias, Ș., Herman, G.V., Study on microbial and fungal contamination of air and wooden surfaces inside of a istorical Church from Romania, In: Journal of Environmental Biology, 2018, 39, 6, 980-984

[5] Gutarowska, B., Pietrzak, K., Machnowski, W., Milczarek, J.M., Historical textiles - a review of microbial deterioration analysis and disinfection methods, In: Textile Research Journal, 2016, 87, 19, 2388-2406

[6] Buchczyk, M., To Weave Or Not To Weave: Vernacular Textiles and Historical Change in Romania, In: Textile, 2014, 12, 3, 328-345

[7] Yu, Y., Cai, M., Zhou, L., Shao, J., Study on the aging and yellowing properties of sebum-soiled cotton fabrics, In: Fibers and Polymers, 2016, 17, 2, 305-309

[8] Gargano, M., Rosina, E., Monticelli, C., Zanelli, A., Ludwig, N., Characterization of aged textile for archeological shelters through thermal, optical and mechanical tests, In: Journal of Cultural Heritage, 2017, 26, 36-43

[9] Triki, E., Dolez, P., Vu-Khanh, T., Tear resistance of woven textiles - Criterion and mechanisms, In: Composites Part B: Engineering, 2011, 42, 7, 1851-1859

[10] Eryuruk, S.H., Kalaoğlu, F., The Effect Of Weave Construction On Tear Strength Of Woven Fabrics, In: Autex Research Journal, 2015, 15, 3, 207-214

[11] Kamel, F.H., Ismael, H.M., Mohammadamin, S.A., Microbial deterioration of historical textiles and approaches for their control, In: International Interdisciplinary Research Journal, 2014, 4, 10-17

[12] Kavkler, K., Gunde-Cimerman, N., Zalar, P., Demšar, A., Fungal contamination of textile objects preserved in Slovene museums and religious institutions, In: International Biodeterioration \& Biodegradation, 2015, 97, 51-59

[13] Kavkler, K., Šmit, Ž., Jezeršek, D., Eichert, D., Demšar, A., Investigation of biodeteriorated historical textiles by conventional and synchrotron radiation FTIR spectroscopy, In: Polymer Degradation and Stability, 2011, 96, 6, 1081-1086

[14] Kangwansupamonkon, W., Lauruengtana, V., Surassmo, S., Ruktanonchai, U., Antibacterial effect of apatitecoated titanium dioxide for textiles applications, In: Nanomedicine: Nanotechnology, Biology and Medicine, 2009, $5,2,240-249$

[15] Sutcliffe, H., Cooper, M., Farnsworth, J., An initial investigation into the cleaning of new and naturally aged cotton textiles using laser radiation, In: Journal of Cultural Heritage, 2000, 1, S241-S246

[16] Quye, A., Factors influencing the stability of man-made fibers: A retrospective view for historical textiles, In: Polymer Degradation and Stability, 2014, 107, 210-218

[17] Gulmini, M., Idone, A., Diana, E., Gastaldi, D., Vaudan, D., Aceto, M., Identification of dyestuffs in historical textiles: Strong and weak points of a non-invasive approach, In: Dyes and Pigments, 2013, 98, 1, 136-145

[18] Tissera, N.D., Wijesena, R.N., Perera, J.R., de Silva, K.M.N., Amaratunge, G.A.J., Hydrophobic cotton textile surfaces using an amphiphilic graphene oxide (GO) coating, In: Applied Surface Science, 2015, 324, 455-463 
[19] Akyuz, T., Akyuz, S., Balci, K., Gulec, A., Investigations of historical textiles from the Imperial Pavilion (Hunkar Kasri) of the new mosque Eminonu-Istanbul (Turkey) by multiple analytical techniques, In: Journal of Cultural Heritage, 2017, 25, 180-184

[20] Patra, J.K., Gouda, S., Patra, K., Application of nanotechnology in textile engineering: An overview, In: Journal of Engineering and Technology Research, 2013, 5, 5, 104-111

[21] Tayel, A.A., Moussa, S.H., El-Tras, W.F., Elguindy, N.M., Opwis, K., Antimicrobial textile treated with chitosan from Aspergillus niger mycelial waste, In: International Journal of Biological Macromolecules, 2011, 49, 2, 241-245

[22] Ivanova, N.A., Philipchenko, A.B., Superhydrophobic chitosan-based coatings for textile processing, In: Applied Surface Science, 2012, 263, 783-787

[23] Hosseinnejad, M., Jafari, S.M., Evaluation of different factors affecting antimicrobial properties of chitosan, In: International Journal of Biological Macromolecules, 2016, 85, 467-475

[24] Kean, T., Thanou, M., Biodegradation, biodistribution and toxicity of chitosan, In: Advanced Drug Delivery Reviews, 2010, 62, 1, 3-11

[25] Dash, M., Chiellini, F., Ottenbrite, R.M., Chiellini, E., Chitosan - A versatile semi-synthetic polymer in biomedical applications, In: Progress in Polymer Science, 2011, 36, 8, 981-1014

[26] Ngo, D.-H., Vo, T.-S., Ngo, D.-N., Kang, K.-H., Je, J.-Y., Pham, H.N.-D, Kim, S.-K., Biological effects of chitosan and its derivatives, In: Food Hydrocolloids, 2015, 51, 200-216

[27] Ivanova, N.A., Philipchenko, A.B., Superhydrophobic chitosan-based coatings for textile processing, In: Applied Surface Science, 2012, 263, 783-787

[28] Viju, S., Thilagavathi, G., Effect of chitosan coating on the characteristics of silk-braided sutures, In: Journal of Industrial Textiles, 2012, 42, 3, 256-268

[29] Varesano, A., Vineis, C., Aluigi, A., Rombaldoni, F., Tonetti, C., Mazzuchetti, G., Antibacterial efficacy of polypyrrole in textile applications, In: Fibers and Polymers, 2013, 14, 1, 36-42

[30] Tayel, A.A., Moussa, S.H., El-Tras, W.F., Elguindy, N.M., Opwis, K., Antimicrobial textile treated with chitosan from Aspergillus niger mycelial waste, In: International Journal of Biological Macromolecules, 2011, 49, 2, 241-245

[31] Hebeish, A., El-Naggar, M.E., Fouda, M.M.G., Ramadan, M.A., Al-Deyab, S.S., El-Rafie, M.H., Highly effective antibacterial textiles containing green synthesized silver nanoparticles, In: Carbohydrate Polymers, 2011, 86, 2, 936-940

[32] Abbott, L.C., Batchelor, S.N., Smith, J.R.L., Moore, J.N., Resonance Raman and UV-visible spectroscopy of black dyes on textiles, In: Forensic Science International, 2010, 202, 1-3, 54-63

[33] Zlatev, Z., Ilieva, J., Design of textile patterns by using colors from the Bulgarian national costumes, In: Applied research on technics, technology end education (ARTTE), 2015, 3, 4, 309-316

[34] Munoz-Price, L.S., Poirel, L., Bonomo, R.A., Schwaber, M.J., Daikos, G.L., Cormican, M., et al., Clinical epidemiology of the global expansion of Klebsiella pneumoniae carbapenemases, In: Lancet Infect Dis., 2013, 13, 9, 785-96

[35] Prabaker, K., Lin, M.Y., McNally, M., Cherabuddi, K., Ahmed, S., Norris, A., The transfer from long-term acute care facilities is associated with the transport of Enterobacteriaceae producing carbapenem Klebsiella pneumoniae: a multihospital study, In: Infect Control Hosp Epidemiol, 2012, 33, 12, 1193-1199

[36] Yan, Z., Zhou, Y., Du, M., Bai, Y., Liu, B., Gong, M., Song, H., Tong, Y., Liu, Y., Prospective investigation of carbapenem-resistant transmission among the staff, environment and patients in five major intensive care units, Beijing, In: J Hosp Infect., 2019, 101, 2, 150-157

Authors:

EVA BOU-BELDA ${ }^{1}$, LILIANA INDRIE², DORINA CAMELIA ILIEȘ ${ }^{3}$, NICOLAIE HODOR $^{4}$, ZHARAS BERDENOV ${ }^{5}$, GRIGORE HERMAN ${ }^{3}$, TUDOR CACIORA ${ }^{3}$

${ }^{1}$ Universitat Politècnica de València, Textile and Paper Department, Plaza Ferrándiz y Carbonell s/n, 03801, Alcoy, Spain e-mail: evbobel@upvnet.upv.es

2University of Oradea, Faculty of Energy Engineering and Industrial Management, Department of Textile, Leather and Industrial Management, B.St. Delavrancea Str., no. 4, 410058, Oradea, Romania

${ }^{3}$ University of Oradea, Faculty of Geography, Tourism and Sport, $1^{\text {st }}$ University Street, Oradea, 410087, Romania e-mail: iliesdorina@yahoo.com, grigoreherman@yahoo.com, tudor.caciora@yahoo.com

${ }^{4}$ Babes-Bolyai University, Clinicilor Street, no. 5-6, Cluj Napoca, Cluj County, Romania e-mail: nicuhodor@yahoo.com

${ }^{5}$ L.N.Gumilyov Eurasian National University, Department of Physical and Economic Geography, Faculty of Science, Satpayev Str., 2, 010008, Nur-Sultan, Republic of Kazakhstan e-mail: berdenov-z@mail.ru

Corresponding author:

LILIANA INDRIE

e-mail: liliindrie@yahoo.com 